\title{
Trans-Amazon Drilling Project (TADP): origins and evolution of the forests, climate, and hydrology of the South American tropics
}

\author{
P. A. Baker ${ }^{1,2}$, S. C. Fritz ${ }^{3}$, C. G. Silva ${ }^{4}$, C. A. Rigsby ${ }^{2,5}$, M. L. Absy ${ }^{6}$, R. P. Almeida ${ }^{7}$, M. Caputo ${ }^{8}$, \\ C. M. Chiessi ${ }^{7}$, F. W. Cruz ${ }^{7}$, C. W. Dick ${ }^{9}$, S. J. Feakins ${ }^{10}$, J. Figueiredo ${ }^{11}$, K. H. Freeman ${ }^{12}$, C. Hoorn ${ }^{13}$,

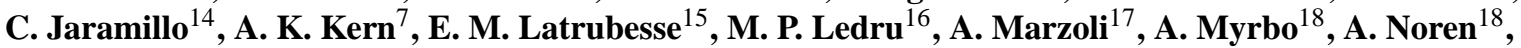 \\ W. E. Piller ${ }^{19}$, M. I. F. Ramos ${ }^{20}$, C. C. Ribas ${ }^{6}$, R. Trnadade ${ }^{21}$, A. J. West ${ }^{10}$, I. Wahnfried ${ }^{22}$, and \\ D. A. Willard ${ }^{23}$ \\ ${ }^{1}$ Earth and Ocean Sciences, Duke University, Durham, NC 27708, USA \\ ${ }^{2}$ Yachay Tech University, San Miguel de Urcuquí, Imbabura, Ecuador \\ ${ }^{3}$ Earth and Atmospheric Sciences, University of Nebraska - Lincoln, Lincoln, NE 68588-0340, USA \\ ${ }^{4}$ Departamento de Geologia, Universidade Federal Fluminense, Niterói, Brazil \\ ${ }^{5}$ Department of Geological Sciences, East Carolina University, Greenville, NC, USA \\ ${ }^{6}$ Instituto Nacional de Pesquisas da Amazônia, Manaus, Brazil \\ ${ }^{7}$ School of Arts, Sciences and Humanities, Universidade de São Paulo, São Paulo, Brazil \\ ${ }^{8}$ Geoarte Consultoria Geológica e Artística Ltda, Belém, Brazil \\ ${ }^{9}$ Department of Ecology and Evolutionary Biology, University of Michigan, Ann Arbor, MI, USA \\ ${ }^{10}$ Department of Earth Sciences, University of Southern California, Los Angeles, CA, USA \\ ${ }^{11}$ OGX Oil and Gas, Brazil \\ ${ }^{12}$ Department of Geosciences, Pennsylvania State University, State College, PA, USA \\ ${ }^{13}$ Institute for Biodiversity and Ecosytem Dynamics, University of Amsterdam, Amsterdam, the Netherlands \\ ${ }^{14}$ Smithsonian Tropical Research Institute, Panama City, Panama \\ ${ }^{15}$ Department of Geography, University of Texas, Austin, TX, USA \\ ${ }^{16}$ Institut de Recherche pour le Développement, Université de Montpellier, Montpellier, France \\ ${ }^{17}$ Dipartimento di Geoscienze, Universitá Degli Studi di Padova, Padua, Italy \\ ${ }^{18}$ Limnological Research Center, University of Minnesota - Twin Cities, Minneapolis, MN, USA \\ ${ }^{19}$ Institute of Earth Sciences, Universität Graz, Graz, Austria \\ ${ }^{20}$ Museu Paraense Emílio Goeldi, Pára, Brazil \\ ${ }^{21}$ Faculdade de Oceanografia, Universidade do Estado do Rio de Janeiro, Rio de Janeiro, Brazil \\ ${ }^{22}$ Departamento de Geociências, Universidade Federal do Amazonas, Manaus, Brazil \\ ${ }^{23}$ US Geological Survey, Reston, VA, USA \\ Correspondence to: P. A. Baker (pbaker@duke.edu)
}

Received: 17 September 2015 - Revised: 13 November 2015 - Accepted: 30 November 2015

- Published: 17 December 2015

Abstract. This article presents the scientific rationale for an ambitious ICDP drilling project to continuously sample Late Cretaceous to modern sediment in four different sedimentary basins that transect the equatorial Amazon of Brazil, from the Andean foreland to the Atlantic Ocean. The goals of this project are to document the evolution of plant biodiversity in the Amazon forests and to relate biotic diversification to changes in the physical environment, including climate, tectonism, and the surface landscape. These goals require long sedimentary records from each of the major sedimentary basins across the heart of the Brazilian Amazon, which can only be obtained by drilling because of the scarcity of Cenozoic outcrops. The proposed drilling will provide the first long, nearly continuous regional records of the Cenozoic history of the forests, their plant diversity, and 
the associated changes in climate and environment. It also will address fundamental questions about landscape evolution, including the history of Andean uplift and erosion as recorded in Andean foreland basins and the development of west-to-east hydrologic continuity between the Andes, the Amazon lowlands, and the equatorial Atlantic. Because many modern rivers of the Amazon basin flow along the major axes of the old sedimentary basins, we plan to locate drill sites on the margin of large rivers and to access the targeted drill sites by navigation along these rivers.

\section{Introduction}

The origin of the great biodiversity observed in tropical South America has spurred debate for well over a hundred years (Darwin, 1859; Agassiz and Agassiz, 1868; Wallace, 1878 ) and remains one of the foundational problems in modern science. Wallace (1878) suggested that low tropical extinction rates, resulting from a relatively equitable and stable tropical climate, enabled the progressive accumulation of species throughout the Cenozoic, a hypothesis that has been termed the "museum" model. In contrast, the "cradle" model (Stebbins, 1974) posits that most tropical diversity arose from episodic pulses of speciation associated with climatic and geological drivers (Richardson et al., 2001). Some propose that the majority of present-day species originated prior to the Pleistocene (Hoorn et al., 2010) and that species origination rates were shaped primarily by geological agents of vicariance, such as Andean uplift, tectonic arches, marine incursions, fluvial barriers, and the expansion of megawetlands. Others argue for significant Quaternary diversification, influenced by the temporal and spatial dynamism of regional climate (Rull, 2011). These different interpretations of the patterns and drivers of tropical biodiversity can best be resolved by recovering the entire Cenozoic record of plant diversity in the Amazon region itself and by placing these biotic data into a well-resolved geologic, climatic, phylogenetic, and biogeographic framework.

We propose an ambitious ICDP drilling project that will continuously sample Upper Cretaceous to modern sediment to $1-2 \mathrm{~km}$ depth at five sites in four different ancient sedimentary basins that transect the equatorial Amazon region of Brazil, from the Andean foreland to the Atlantic Ocean margin (Fig. 1). The overarching goals of this project are (1) to document the assembly of Amazon plant diversity across the entire basin throughout the entire history of the angiospermdominated megathermal forests, and (2) to determine how the evolution of the physical environment, including climate, tectonism, and landscape change, has shaped the generation and distribution of neotropical plant diversity and the origins of its species and higher-level taxa. These goals require long sedimentary records distributed across the continent, which, in most of the Amazon region, can only be obtained by drilling.

The Cenozoic geology of the westernmost (proximal Andean) and easternmost (offshore Foz do Amazonas basin) parts of the Amazon region is better known than that of the central Brazilian Amazon, where we propose to drill. In the far western Peruvian, Ecuadorean, and Colombian Amazon, ongoing uplift of Andean foreland basin sequences provides outcrops of Cenozoic sediments that are relatively easily accessed. Yet even here, complete and continuous sections are non-existent. Beyond the eastern limit of the Amazon region, on the Ceará Rise far offshore of the mouth of the Amazon, drilling during ODP Leg 154 recovered long sequences of sediment with some Amazonian provenance (Dobson et al., 2001; Harris and Mix, 2002). Even longer stratigraphic records were recovered in industry exploration wells on the Amazon slope and shelf, which were dated using marine microfossils. But these sections are poor records of continental history, because they are distal to the Amazon basin itself and because continental indicators of climate and biotic history are greatly diluted by marine influences. In the heart of the central Brazilian Amazon, Cenozoic outcrops are scarce, vegetation-covered, and deeply weathered - the critical sedimentary sequences are only available in the subsurface. And, despite extensive hydrocarbon exploration undertaken in this region, including many deep drill cores and thousands of kilometers of seismic lines, little is known about the nonpetroleum-bearing shallow (Cenozoic age) part of the sedimentary record, which holds key information about the evolution of the modern rainforest and the establishment of the Amazon river drainage system. Most of the samples that are still available are decades old, composed only of cuttings, undated, in poor condition, and sometimes contaminated, and also relatively difficult to access even by Brazilian scientists. Thus, collecting continuous, fresh drill cores from the central Amazon region is critical.

In March 2015, we held a 3-day ICDP-sponsored workshop at the Instituto Nacional de Pesquisas da Amazônia in Manaus, Brazil, to discuss the scientific framework for the TADP, to identify and begin to resolve technical and logistical issues, and to further develop the international team needed for carrying out the drilling and associated science. Thirty scientists from eight nations in the Americas and $\mathrm{Eu}-$ rope attended. The first day included overview presentations on the history of the Amazon forest and its biodiversity and on the geologic history of the Amazon and Andes, as well as presentations on recent research results on more specific topics. The second day was devoted to small group discussions of methodological and logistical issues, followed by discus- 


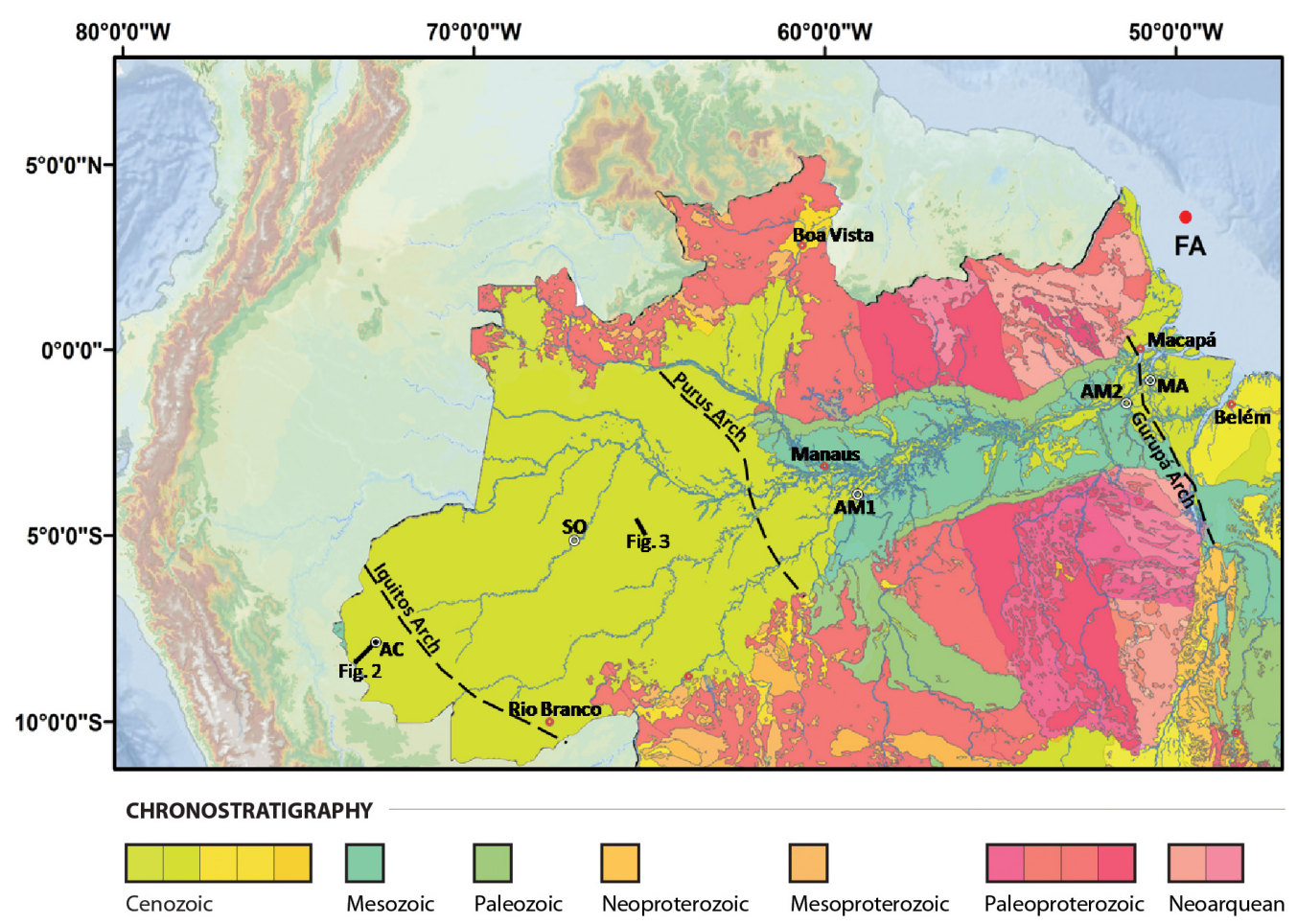

Figure 1. Geologic map of the Amazon region. Note that the newly revised geologic map of Brazil shows that the sedimentary cover of the Amazon basin is Cenozoic (not Cretaceous as shown here; see Caputo, 2011). Also shown are the locations of seismic lines in Figs. 2 and 3 and proposed drill sites. Drill site locations are shown for the Acre (AC), Solimões (SO), Amazon (AM), and Marajó (MA) basins. Each of these basins is separated from the adjoining basin by structural arches, as shown on the figure.

sions on how to develop the drilling plans and effectively interface with ICDP, IODP, various Brazilian organizations, and other related international efforts. The final day featured a field trip led by Edgardo Latrubesse, visiting the flooded Igapó forests and white sand beaches along the Rio Negro, as well as the "Meeting of the Waters" at the confluence of the black-water Rio Negro and the white-water Rio Solimões.

\section{The geographic framework of the Brazilian Amazon}

South America is a continent, more so than any other, whose land surface is dominated by large rivers. Many of these modern rivers flow along the major axes of old sedimentary basins. The Brazilian Amazon region itself (Fig. 1) is largely comprised of a series of east-west trending basins that began accumulating sediments in the Paleozoic, overlying and bounded north and south by Precambrian continental basement rocks. From west to east these basins are the Acre, Solimões, Amazon, Marajó, and Foz do Amazonas (which includes the Amazon deep-sea fan); all of these basins have several kilometers of sediment fill (Cunha, 2007; Cunha et al., 2007; Figueiredo et al., 2007; Filho et al., 2007, Zalán and Matsuda, 2007). This geographic coincidence is significant for the proposed drilling, because it means that the modern Amazon river provides easy access to several different sites where, by drilling along the river margins, we can access nearly the entire Cenozoic history of the Amazon forest and its climate. Each of the Amazon sedimentary basins is separated from its neighbor by structural highs that displace basement rocks, have been reactivated many times in the Phanerozoic, and, in some cases, may remain active to the present day. From west to east these structural features are the Iquitos Arch, Purus Arch, Gurupá Arch, and an un-named structural high Amazon basin. Some of these features have previously been posited as topographic highs that played a role in the development of Amazon transcontinental drainage (Figueiredo et al., 2009) or the origins of Amazon biodiversity (Patton et al., 2000; Ribas et al., 2011).

\section{The temporal development of the Amazon basin and its forests}

In the Cretaceous, the South American continent occupied nearly the same latitude as today, but its tropical forests were dominated by gymnosperms and ferns and hence were completely different than modern forests (Morley, 2000; Graham, 2011; Jaramillo, 2012). The rise of angiosperms in the Early Cretaceous initiated major changes in the structure, func- 
tion, and composition of the forest, changes that may have been influenced by the nearby Chicxulub impact event at the Cretaceous-Tertiary boundary. That event and the ensuing cascade of environmental responses brought about extinction of an estimated $48-70 \%$ of the neotropical terrestrial plant species (de la Parra, 2009). The subsequent expansion of angiosperm megathermal forests has been linked to greenhouse climates (Morley, 2000; Fine and Ree, 2006), and studies from northern South America suggest that species diversity of forest plants increased in the early Cenozoic under warm conditions (Jaramillo et al., 2006), with the development of the neotropical rainforest at the onset of the Eocene (Morley, 2000). Palynofloral data from multiple sections in Colombia and Venezuela that span the Paleocene through Early Miocene (65 to $20 \mathrm{Ma}$ ) suggest maximum diversity at the Paleocene-Eocene Thermal Maximum (PETM) as a result of rapid plant diversification and biogeographic mixing (Jaramillo et al., 2006, 2010), followed by a subsequent decline, a pattern that mirrors global temperature reconstructions (Jaramillo et al., 2006). At least on the face of it, given the scant data, it appears that the early-mid-Cenozoic climatic "optimum" was an evolutionary "optimum", inviting the suggestion that rainforest plant taxa may survive and thrive in future global warming scenarios (Willis et al., 2010; Dick et al., 2013). Yet all of these studies of palynofloral diversity through time were undertaken outside the margins of the modern Amazon basin itself. Furthermore, no Paleogene sediments have been recovered and described from the Brazilian Amazon, and the published data from Neogene sequences from exploration wells and outcrops are largely from western Amazonia (Hoorn, 1993; Silva-Caminha et al., 2010). Thus, our knowledge of the history of the forests and forest diversity in the core of the Amazon Basin, and the associated climate history, is almost nonexistent. Recovering, dating, and analyzing Paleogene sediments from the drill cores for the first time is a major objective of this project.

A fundamental premise of much previous research on the history of South American tropical forests is that Andean surface uplift played a major role in the origin and distribution of neotropical biodiversity (Hoorn et al., 2010). Andean uplift sundered populations east and west, promoting their biological differentiation; it created new high-elevation habitats; it altered precipitation patterns and amounts; and it provided nutrients to the adjacent lowland rivers and forests.

The Andes developed along a Cenozoic convergent margin, where the oceanic Nazca plate subducts beneath South America. The Andes of Ecuador, Peru, and Bolivia consist of two parallel ranges: the Western Cordillera (WC) magmatic arc and the Eastern Cordillera (EC) fold-thrust belt. The timing of surface uplift and its spatial variation remain very poorly known, particularly in the case of the WC. Recent investigations in southern Peru suggest that modern WC elevations were attained about $\sim 19-16 \mathrm{Ma}$ (Saylor and Horton, 2014). EC deformation and exhumation began in the Eocene with the so-called Incaic Orogeny (Megard, 1978;
McQuarrie, 2002; Elger et al., 2005; Gillis et al., 2006). In contrast, in the northern Bolivian Altiplano, which lies between the WC and EC, Garzione et al. (2006) and Ghosh et al. (2006) concluded that surface uplift was rapid and occurred between $\sim 10$ and $6 \mathrm{Ma}$. But their clumped isotopic paleoaltimetry estimates have been challenged (Ehlers and Poulsen, 2009; Poulsen et al., 2010; Insel et al., 2010; Garreaud et al., 2010; Barnes et al., 2008. In general, the emerging data suggest that the timing, rates, and mechanisms of uplift are not spatially uniform (Saylor and Horton, 2014). One of the best ways to constrain Andean uplift and erosion history and to disentangle the influences of climate and topography in affecting Andean isotopic records will be to determine the provenance and paleoclimate history of the everlowland sediments in drill cores recovered from the proposed drill site in the Acre foreland basin.

Much of western Amazonia was composed of actively subsiding foreland basins from the early Cenozoic to the present and, throughout this time, received sediments eroded from the Andes. In the early Cenozoic, the Amazon basin may have drained westward, then northward, while only the eastern third of the craton drained toward the Atlantic. At some later time, with estimates ranging widely between Miocene and Pleistocene, the Amazon system became a transcontinental fluvial basin (Hoorn et al., 2010; Latrubesse et al., 2010), and Andean sediments first reached the Atlantic basin.

Prior to establishment of trans-Amazon drainage, by some accounts, the Purus Arch (Fig. 1) formed the western limit of proto-Amazon drainage, possibly as late as the Pleistocene (Vega et al., 2006; Mapes, 2009). A counter point of view is that the Purus Arch was tectonically inactive during all of the Cenozoic and played no role as a drainage divide. Instead, it may have been the Gurupá Arch (Fig. 1), having undergone more than $5 \mathrm{~km}$ of total uplift since the opening of the Atlantic (Caputo, 2011), which was the key hydrologic barrier to eastward flow of the early Amazon. Yet the role of the Gurupá Arch in Amazon hydrology and biogeography has never been discussed in the literature.

During the Miocene, sedimentary sequences of the Pebas Formation in Peru or the equivalent Solimões Formation in Brazil reached a maximum thickness of $1100 \mathrm{~m}$ in the Acre Basin. However, interpretations of the age and depositional environment of these sediments are varied and controversial. Wesselingh (2006) argued for the existence of a longlived (15 Ma) freshwater mega-lake or mega-wetland bisecting western Amazonia during the entire Early and Middle Miocene. Several studies from the early 1990s (Nutall, 1990; Hoorn, 1993) suggested that recurrent marine transgressions into the Amazon basin occurred during global sea-level high stands of the Miocene, and Räsänen et al. (1995) proposed that these extended all the way to southern Peru in the Late Miocene. In more recent literature, marine incursions or tidal influences of variable timing and spatial extent have been posited in multiple sedimentary models for Amazonia (e.g., 
Hovikoski et al., 2010; Hoorn et al., 2010; Boonstra et al., 2015). Yet the sedimentary structures and trace fossils proposed as marine are not uniquely associated with tidal systems (e.g., Westaway, 2006; Latrubesse et al., 2010). Constraining the nature and timing of the Amazon sedimentary environment with new drill cores across the basin is important, because many of these inadequately constrained aspects of the geological evolution of the Andes and Amazon have been invoked in biogeographic and phylogeographic models as barriers to gene flow and drivers of species diversification.

Controversy also surrounds the role of climate in driving neotropical speciation. Some argue that the majority of present-day species originated prior to the Pleistocene (Hoorn et al., 2010) and that species origination rates were largely independent of climate, thus shaped primarily by geological agents of vicariance, including uplift, marine incursions, mega-wetlands, riverine barriers, and arches. For example, Ribas et al. (2011) documented phylogenetic patterns in the flightless birds, the trumpeters (Aves Psophia), and demonstrated that their evolutionary history follows that of major lowland Amazon river drainages, suggesting a fundamental role for fluvial evolution, not climate variability, in bird diversification over the last $3 \mathrm{Ma}$. In contrast, other workers argue that species origins in the Amazon were the direct result of climate variability or at least that climate played a significant role (Rull, 2011). An early model of climate-influenced speciation is the refugia hypothesis (Haffer, 1969), which posits that during Pleistocene dry periods, the Amazon forest contracted into refugia and that populations isolated in these refugia underwent accelerated rates of diversification. Although most data suggest that the refugia hypothesis may not be correct in its original definition (Rull, 2011), this does not negate the possibility of considerable diversification during the Quaternary associated with climateinduced vegetation fragmentation and expansion (e.g., Cheng et al., 2013). These (and many other) different interpretations of the rates and drivers of tropical biodiversity can only begin to be resolved by recovering the entire Cenozoic record of plant diversity in the Amazon region itself and placing the biotic data into a well-resolved geologic, climatic, phylogenetic, and biogeographic framework.

\section{Major questions to be addressed by drilling}

1. What is the history of plant diversity across the Amazon basin? Is the Amazon a "museum", steadily accumulating diversity through time? Or does diversity covary with global temperature, perhaps as a result of areal expansion of the tropics? How does diversity respond to specific environmental drivers, such as Andean uplift? Are there any clear extinction events throughout the Amazon forest? What is the sequence of turnover of dominant plant families and genera across the basin? When did Andean-centered plant taxa expand across the basin? What was the nature of biotic change in the Amazon region across the Cretaceous-Paleogene boundary (e.g., de la Parra, 2009)? Contemporary $\alpha$-diversity of trees is highest in western Amazonia, where precipitation is higher and soils are more fertile than farther east (ter Steege and RAINFOR, 2010). Did this westto-east gradient persist throughout the Cenozoic? Is climate and diversity in some parts of the Amazon (for example, in the presently wetter western Amazon) more stable through time than in other regions? The species composition of the contemporary Amazon forest differs significantly between different localities (ter Steege et al., 2013), so reconstructing past biodiversity requires sampling across the entire region. Thus, non-similarity between paleo-biota from tropical and subtropical latitudes (Jaramillo and Cardenas, 2013) does not preclude the possibility that both latitudes hosted a continuous Amazon-type rainforest.

2. What is the history of tropical South American climate from the Late Cretaceous to today? Does the Cenozoic thermal history of the Amazon region mirror the global history that we deduce from the deep-sea oxygen isotopic record (Zachos et al., 2001)? Were thermal optima relatively wet or dry periods? The Held and Soden (2006) model predicts a wetter Amazon in past thermal maxima and a drier Amazon in past cold periods. Was this in fact the case? Or did an east-west equatorial precipitation dipole persist throughout the whole Cenozoic as has been reconstructed from late Quaternary speleothems (Cheng et al., 2013)? Did the progressive widening of the Atlantic Ocean and the developing east-west equatorial Pacific zonal sea surface temperature gradient during the Cenozoic imprint themselves on the hydrologic record of the Amazon? Is there any evidence for increasing dryness during the Cenozoic as has been reconstructed for other tropical localities (e.g., Sepulchre et al., 2006)?

3. What is the history of Andean uplift and erosion as recorded in Andean foreland basins? The Acre foreland basin is ideal for this purpose, because it is sufficiently proximal to the Andes to receive detrital input, yet sufficiently distal from the Andes to have a relatively slow and continuous rate of accumulation of finer-grained sediment most amenable to paleoecological study. We expect Andean provenance to be well recorded in both the Acre and the Solimões basins. Specifically we will test the alternative hypotheses (1) that the portion of the Andes located to the west of this region was highstanding and provided sediment to the Acre Basin throughout the entire Cenozoic, or (2) that the Andes only underwent significant uplift in the Late Miocene.

4. When did west-to-east hydrologic continuity develop between the Amazon basin and the equatorial Atlantic? 
sw

NE

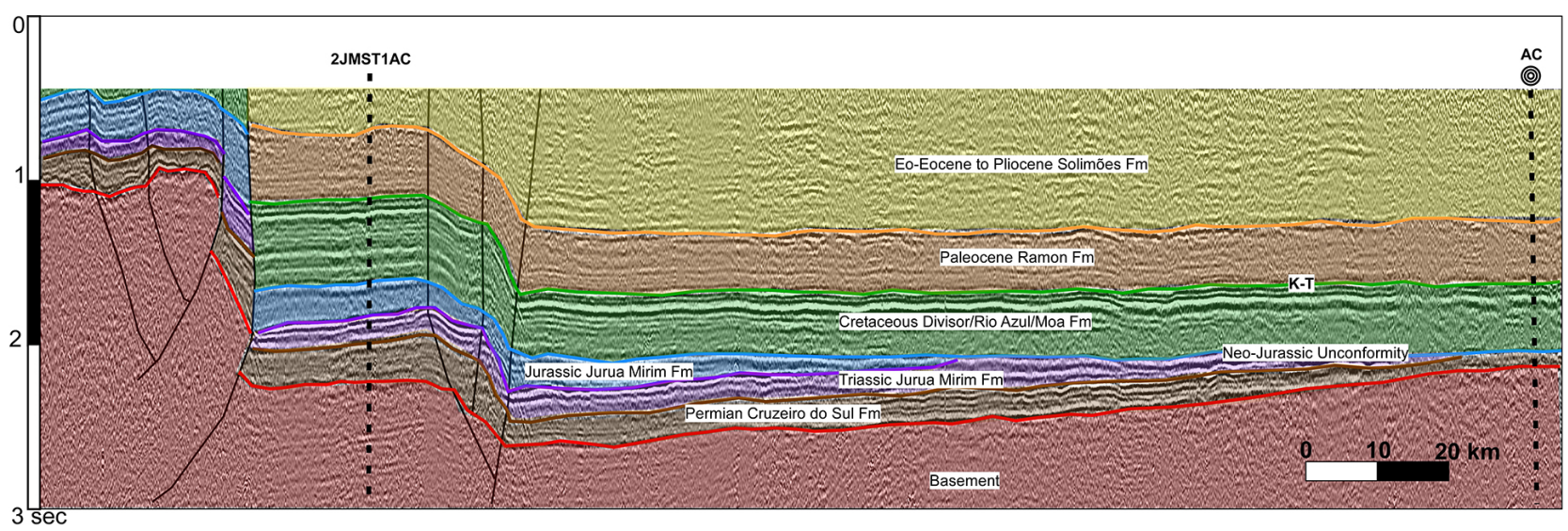

Figure 2. Seismic reflection profile from the Acre Basin (location of line shown in Fig. 1). The proposed drill hole location (AC) and previous drill hole location (2JMST1AC) are shown.

Did the Purus Arch act as an ancient hydrologic divide between eastward and westward drainage? Did the Gurupá Arch form the ultimate divide between the western Amazon drainages and the Atlantic Ocean? Did these structural arches serve as geographic barriers as posited by Patton et al. (2000)? Did the main-stem Amazon or its major tributaries present barriers to taxa inhabiting opposite banks of the rivers (e.g., Ribas et al., 2011)? Can we date the origins of the through-flowing Amazon, providing better constraints for molecular dating of taxonomic divergence (Baker et al., 2014)?

\section{Potential new drilling targets emerging from workshop discussions}

The thickest volumes of the entire Central Atlantic Magmatic Province (CAMP, Marzoli et al., 1999) are preserved in the sedimentary basins of the Amazon. Workshop participant, Andrea Marzoli, discussed the exciting potential for drilling into this key stratigraphic unit to uncover its volume, origins, and timing of formation. CAMP magmatism caused rapid global perturbations through the emission of volcanic gases and was associated with the break-up of Pangaea, the opening of the Atlantic Ocean, and the mass extinction event at the Triassic-Jurassic boundary (Marzoli et al., 2004; Schoene et al., 2010; Ruhl et al., 2011). Intruded magmas occur within the Paleozoic sedimentary sequences of the Amazon and Solimões basins (Fig. 3) and reach up to a kilometer in thickness and can be traced over distances of nearly $1000 \mathrm{~km}$. Geochemical and geochronological analysis of these extensive units can be used to test hypotheses regarding the origins of CAMP and its global impacts.

The outcropping sedimentary formations of the Amazon basin also host one of the largest aquifers in the world (Wahnfried and Soares, 2012). Workshop participant, Ingo Wahn- fried, argued that the drilling of the Cenozoic and older sediments of the Amazon region will provide important constraints on the volume, age, geochemistry, flow rates, and residence time of groundwater units and the connectivity of surficial and shallow units with deeper transmissive layers. The aquifers are important conduits between surface and the subsurface environments, and access to aquifers may also provide important insights into biogeochemical processes, as well as the deep biosphere and the diversity of Amazonian subsurface microbial communities.

\section{Site selection and logistics of drilling}

We have reviewed seismic reflection and well log data from all four of the continental Brazilian Amazon basins, and we have identified five continental drilling sites, all easily accessible, located on pre-existing seismic lines, and located near pre-existing drill holes with available well log and lithologic data. We are working with the Brazilian drilling company Geosol to develop a detailed proposal for carrying out the drilling operations, employing either a Boart Longyear LF or Atlas Copco CT 20 drill rig. Both have capabilities to drill to more than $1500 \mathrm{~m}$ with HQ diameter cores or nearly $2500 \mathrm{~m}$ with $\mathrm{N}$ diameter cores. The drill sites will all be located on the margins of large navigable rivers (the Juruá, the Amazon, the Straits of Breves), allowing transport of equipment and personnel by barge. Drilling will involve offloading the drilling vehicle at a port or temporary landing and installation on a pre-prepared drilling pad. All personnel will be housed in a hotel boat adjacent to the drill site. All drilling will be undertaken with blow-out prevention due to the possibility of encountering shallow gas accumulations in this region. Drilling muds will be chosen with consideration to minimizing contamination for organic geochemistry while maximizing core recovery and drilling rate. 


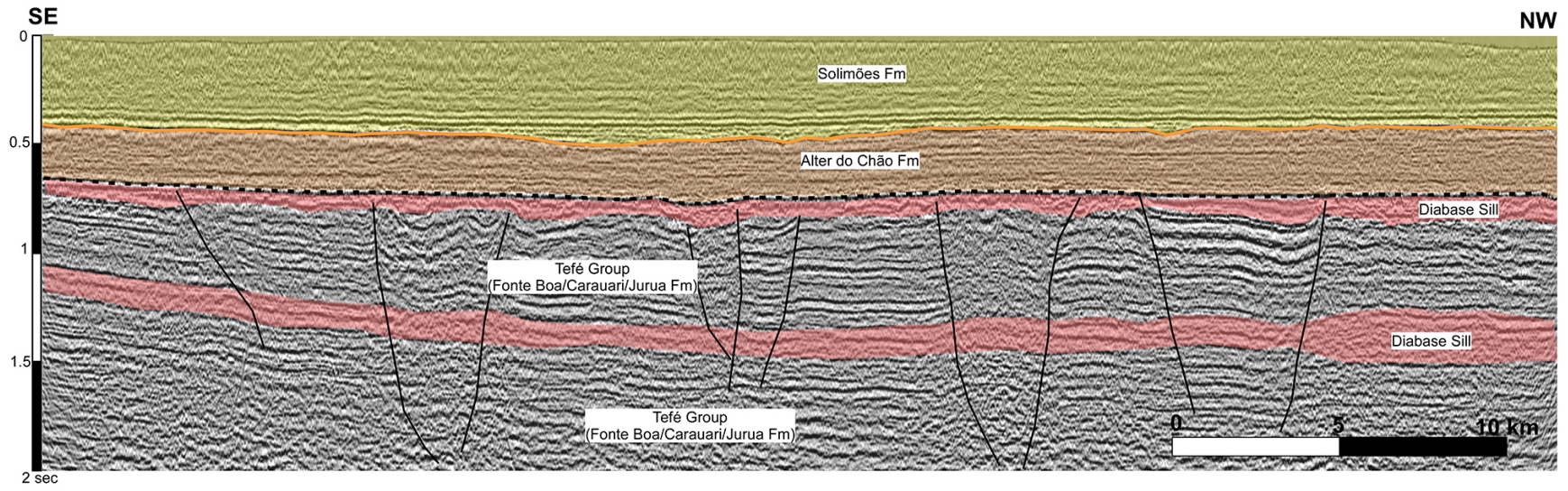

Figure 3. Seismic reflection profile from the Solimões Basin (location of line shown in Fig. 1). Here, the Alter do Chão Formation is illustrated to be Cenozoic (Caputo, 2011), not Cretaceous, as previously believed. Multiple diabase sills and interbedded sediments unconformably underlie Cenozoic sediments in this region. The proposed (SB) drill hole will encounter the same stratigraphic column as shown in the seismic line, but is located more accessibly on the Rio Juruá.

In the westernmost Acre Basin, thick Cenozoic foreland basin sequences will require our deepest drilling, perhaps $2 \mathrm{~km}$ total depth, in order to reach the Cretaceous-Paleogene boundary (Fig. 2). In the Solimões Basin site (Fig. 3), a thinner sequence of the Mio-Pliocene Solimões Formation conformably overlies the Paleocene-to-Miocene-age (Caputo, 2011) Alter do Chão Formation that, in turn, unconformably overlies the "Penatecaua" diabase sills. In this site, we aim to recover a sequence of $750 \mathrm{~m}$ of Cenozoic sediments overlying a complete sequence (ca. $900 \mathrm{~m}$ total) of four diabase sills and interbedded sediments.

On the eastern flank of the Purus Arch, we will drill a site in the western Amazon basin where the Cenozoic sequence is substantially thinner than in the Solimões Basin. A second Amazon site will be located in the far eastern part of the basin on the western flank of the Gurupá Arch, where Cenozoic sediments are appreciably thicker than farther west. This latter site will be paired with a site on the eastern flank of the Gurupá Arch in the northwestern part of the Marajó Basin, where the Cenozoic sequence is $\sim 1 \mathrm{~km}$ thick, shows considerable marine influence, and can be dated by marine biostratigraphy. It is expected that correlation will be possible across the Gurupá Arch over the small distance separating these two sites. In the Marajó site, we expect that the first appearance of detritus with Andean provenance will allow us to date the onset of trans-continental drainage. Elsewhere in the Marajó Basin, rapid (and ongoing) subsidence led to deposition of a Cenozoic sequence as much as $10 \mathrm{~km}$ thick, far beyond our drilling capabilities.

Dating the Cenozoic, mostly fluvial, sediments of the Amazon has been challenging. We expect this to be undertaken by a combination of paleomagnetic stratigraphy, palynostratigraphy, $\mathrm{U}-\mathrm{Pb}$ geochronology, and marine biostratigraphy in the eastern sites proximal to the Atlantic Ocean. Key measurements to be undertaken on all drill cores are pollen identification and quantification to determine biodiversity and its change through time (Jaramillo et al., 2006, 2010); organic geochemical measurements that record past climate, yet are relatively insensitive to diagenetic alteration (Freeman and Pancost, 2014); microfossils and geochemical measurements on carbonate units that can differentiate between fresh, brackish, and marine environments (Gross et al., 2011, 2013); and provenance studies using U-Pb or Nd-Sm or other measurements that will allow dating of connectivity of basins across the continent (Mapes, 2009).

Author contributions. P. A. Baker, S. C. Fritz, and C. G. Silva wrote the manuscript, and Rigsby contributed to the section on site selection. Other co-authors attended the workshop and contributed to the discussion of the ideas and plans presented here.

Acknowledgements. We thank U. Harms and ICDP for funding and facilitating the workshop that motivated this article and Renato de Franca and colleagues for hosting the workshop at INPA. Supported by NSF (FESD) \#1338694 to P. A. Baker, S. C. Fritz, and colleagues. Any use of trade, firm, or product names is for descriptive purposes only and does not imply endorsement by the US Government.

Edited by: T. Wiersberg

Reviewed by: T. Johnson and one anonymous referee 


\section{References}

Agassiz, L. and Agassiz, E.: A Journey in Brazil, Ticknor and Fields, Boston, MA, USA, 540 pp., 1868.

Baker, P. A., Fritz, S. C., Dick, C. W., Eckert, A. J., Horton, B. K., Manzoni, S., Ribas, C. C., Garzione, C. N., and Battisti, D. S.: The emerging field of geogenomics: constraining geological problems with genetic data, Earth Science Reviews, 135, 38-47, 2014.

Barnes, J. B., Ehlers, T. A., McQuarrie, N., O'Sullivan, P. B., and Tawackol, S.: Thermochronometer record of central Andean plateau growth, Bolivia (19.5 degrees S), Tectonics, 27, TC3003, doi:10.1029/2007TC002174, 2008.

Boonstra, M., Ramos, M. I. F., Lammertsma, E. I., Antoine, P.-O., and Hoorn, C.: Marine connections of Amazonia: Evidence from foraminifera and dinoflagellate cysts (early to middle Miocene, Colombia/Peru), Palaeogeography, Palaeoclimatology, Palaeoecology, 417, 176-194, 2015.

Caputo, M. V.: Discussão sobre a Formação Alter do Chão e o Alto de Monte Alegre, Contribuições à Geologia da Amazônia, 7, 723, 2011.

Cheng, H., Sinha, A., Cruz, F. W., Wang, X., Edwards, R. L., d'Horta, F. M., Ribas, C. C., Vuille, M., Stott, L. S., and Auler, A. S.: Climate change patterns in Amazonia and biodiversity, Nature Communications, 4, 1411, doi:10.1038/ncomms2415, 2013.

Cunha, P. R. C: Bacia do Acre, Boletim de Geociências da Petrobras, 15, 207-215, 2007.

Cunha, P. R. C., Melo, J. H. G., and Silva, O. B.: Bacia do Amazonas, Boletim de Geociências da Petrobras, 15, 227-251, 2007.

Darwin, C. W.: On the Origin of Species by Means of Natural Selection or the Preservation of Favored Races in the Struggle for Life, John Murray, London, 502 pp., 1859.

de la Parra, F.: Palynological changes across the CretaceousTertiary boundary in Colombia, South America, MS Thesis, University of Florida, 105 pp., 2009.

Dick, C. W., Lewis, S. L., Maslin, M., and Bermingham, E.: Neogene origins and implied warmth tolerance of Amazon tree species, Ecology and Evolution, 3, 162-169, doi:10.1002/ece3.441, 2013.

Dobson, D. M., Dickens, G. R., and Rea, D. K.: Terrigenous sediments on Ceara Rise: A Cenozoic record of South American orogenesis and erosion, Palaeogeography, Palaeoclimatology, Palaeoecology, 165, 215-229, 2001.

Ehlers, T. A. and Poulsen, C. J.: Influence of Andean uplift on climate and paleoaltimetry estimates, Earth and Planetary Science Letter, 290, 238-248, 2009.

Elger, K., Oncken, O., and Glodny, J.: Plateau-style accumulation of deformation: Southern Altiplano, Tectonics, 24, TC4020, doi:10.1029/2004TC001675, 2005.

Filho, J. R. W., Eiras, J. F., and Vaz, P. T.: Bacia do Solimóes, Boletim de Geociências da Petrobras, 15, 217-225, 2007.

Figueiredo, J., Zalán, P. V., and Soares, E. F.: Bacia da Foz do Amazonas, Boletim de Geociências da Petrobras, 15, 299-309, 2007.

Figueiredo, J., Hoorn, C., van der Ven, P., and Soares, E.: Late Miocene onset of the Amazon River and the Amazon deep-sea fan: Evidence from the Foz do Amazonas Basin, Geology, 37, 619-622, 2009.
Fine, P. V. A. and Ree, R. H.: Evidence for a time-integrated species-area effect on the latitudinal gradient in tree diversity, American Naturalist, 168, 786-804, 2006.

Freeman K. H. and Pancost R. D.: Biomarkers for terrestrial plants and climate, in: Organic Biogeochemistry, edited by: Falkowski, P. and Freeman, K., Treatise on Geochemistry, Elsevier, Amsterdam, 12, 395-416, 2014.

Garreaud, R., Molina, A., and Farias, M.: Andean uplift and Atacama hyperaridity: A climate modeling perspective, Earth Planet. Sc. Lett., 292, 39-50, 2010.

Garzione, C. N., Molnar, P., Libarkin, J. C., and MacFadden, B. J.: Rapid late Miocene rise of the Bolivian Altiplano: Evidence for removal of mantle lithosphere, Earth Planet. Sc. Lett., 241, 543556, 2006.

Ghosh, P., Garzione, C. N., and Eiler, J. M.: Rapid uplift of the Altiplano revealed through ${ }^{13} \mathrm{C}-{ }^{18} \mathrm{O}$ bonds in paleosol carbonates, Science, 311, 511-515, 2006.

Gillis, R. J., Horton, B. K., and Grove, M.: Thermochronology, geochronology, and upper crustal structure of the Cordillera Real: Implications for Cenozoic exhumation of the central Andean plateau, Tectonics, 25, TC6007, doi:10.1029/2005TC001887, 2006.

Graham, A.: The age and diversification of terrestrial New World ecosystems through Cretaceous and Cenozoic time, Am. J. Bot., 98, 336-351, 2011.

Gross, M., Piller, W. E., Ramos, M. I., and Silva Paz, J. D.: Late Miocene sedimentary environments in south-western Amazonia (Solimões Formation; Brazil), J. S. Am. Earth Sci., 32, 169-181, 2011.

Gross, M., Ramos, M. I., Caporaletti, M., and Piller, W. E.: Ostracodes (Crustacea) and their palaeoenvironmental implications for the Solimões Formation (Late Miocene; Western Amazonia/Brazil), J. S. Am. Earth Sci., 42, 216-241, 2013.

Haffer, J.: Speciation in Amazonian forest birds, Science, 165, 131137, 1969.

Harris, S. E. and Mix, A. C.: Climate and tectonic influences on continental erosion of tropical South America, 0-13 Ma, Geology 30, 447-450, 2002.

Held, I. M. and Soden, B. J.: Robust responses of the hydrological cycle to global warming, J. Climate, 19, 5686-5699, 2006.

Hoorn, C.: Marine incursions and the influence of Andean tectonics on the Miocene depositional history of northwestern Amazonia, Palaeogeography, Palaeoclimatology, Palaeoecology, 105, 267309, 1993.

Hoorn, C., Wesselingh, F. P., ter Steege, H., Bermudez, M. A., Mora, A., Sevink, J., Sanmartin, I., Sanchez-Meseguer, A., Anderson, C. L., Figueiredo, J. P., Jaramillo, C., Riff, D., Negri, F. R., Hooghiemstra, H., Lundberg, J., Stadler, T., Sarkinen, T., and Antonelli, A.: Amazonia through time: Andean uplift, climate change, landscape evolution, and biodiversity, Science, 330, 927-931, 2010.

Hovikoski, J., Wesselingh, F. P., Räsänen, M., Gingras, M., and Vonhof, H. B.: Marine influence in Amazonia: evidence from the geological record, in: Amazonia: Landscape and Species Evolution, edited by: Hoorn, C. and Wesselingh, F., Wiley Blackwell, Chichester, 143-161, 2010.

Insel, N., Poulsen, C. J., and Ehlers, T. A.: Influence of the Andes Mountains on South American moisture transport, convection, and precipitation, Clim. Dynam., 35, 1477-1492, 2010. 
Jaramillo, C.: Historia Geológica del Bosque Húmedo Neotropical, Revista de la Academia Colombiana de Ciencias Exactas, Físicas y Naturales, 36, 57-77, 2012.

Jaramillo, C. and Cardenas, A.: Global warming and neotropical rainforests: a historical perspective, Annual Reviews of Earth and Planetary Sciences, 41, 741-766, 2013.

Jaramillo, C., Rueda, M. J., and Mora, G.: Cenozoic plant diversity in the Neotropics, Science, 311, 1893-1896, 2006.

Jaramillo, C., Ochoa, D., Contreras, L., Pagani, M., Carvajal-Ortiz, H., Pratt, L.M., Krishnan, S., Cardona, A., Romero, M., Quiroz, L., Rodriguez, G., Rueda, M., de la Parra, F., Moron, S., Green, W., Bayona, G., Montes, C., Quintero, O., Ramirez, R., Mora, A., Schouten, S., Bermudez, H., Navarrete, R. E., Parra, F., Alvaran, M., Osorno, J., Crowley, L. J., Valencia, V., and Vervoort, J.: Effects of rapid global warming at the Paleocene-Eocene boundary on neotropical vegetation, Science, 330, 957-961, 2010.

Latrubesse, E. M., Cozzuol, M., da Silva-Caminha, S. A. F., Rigsby, C. A., Absy, M. L., and Jaramillo, C.: The Late Miocene paleogeography of the Amazon Basin and the evolution of the Amazon River system, Earth Science Reviews, 99, 99-124, 2010.

Mapes, R. W.: Past and present provenance of the Amazon River, $\mathrm{PhD}$ thesis, University of North Carolina, Chapel Hill, 185 pp., 2009.

Marzoli, A., Renne, P. R., Piccirillo, E. M., Ernesto, M., Bellieni, G., and De Min, A.: Extensive 200 million years old continental flood basalts from the Central Atlantic Magmatic Province, Science, 284, 616-618, 1999.

Marzoli, A., Bertrand, H., Knight, K., Cirilli, S., Buratti, N., Verati, C., Nomade, S., Renne, P., Youbi, N., Martini, R., Allenbach, K., Neuwerth, R., Rapaille, C., Zaninetti, L., and Bellieni, G.: Synchrony of the Central Atlantic magmatic province and the Triassic-Jurassic boundary climatic and biotic crisis, Geology 32, 973-976, 2004.

McQuarrie, N.: The kinematic history of the central Andean foldthrust belt, Bolivia: Implications for building a high plateau, Geol. Soc. Am. Bull., 114, 950-963, 2002.

Megard, F.: Etude geologique des Andes du Peru central, Memoires ORSTOM 86, 517 pp., 1978.

Morley, R. J.: Origin and Evolution of Tropical Rain Forests, John Wiley \& Sons, Chichester, UK, 362 pp., 2000.

Nutall, C. P.: A review of the Tertiary non marine molluscan faunas of the Pebasian and other inland basins of north-western South America, Bulletin of the British Museum of Natural History Geology, 45, 165-371, 1990.

Patton, J. L., da Silva, M. N. F., and Malcolm, J. R.: Mammals of the Rio Juruá and the evolutionary and ecological diversification of Amazonia, Bulletin of the American Museum Natural History, 244, 1-306, 2000.

Poulsen, C. J, Ehlers, T. A., and Insel, N.: Onset of convective rainfall during gradual Late Miocene rise of the Central Andes, Science, 328, 490-493, 2010.

Räsänen, M., Linna, A. M., Santos, J. C. R., and Negri, F. R.: Late Miocene tidal deposits in the Amazonian foreland basin, Science, 269, 386-389, 1995.

Ribas, C. C., Aleixo, A., Nogeuira, A. C. R., Miyaki, C. Y., and Cracraft, J.: Amazonia over the past three million years, Proceedings of the Royal Society of London B, 279, 681-689, doi:10.1098/rspb.2011.1120, 2011.
Richardson, J. E., Pennington, R. T., Pennington, T. D., and Hollingsworth, P. M.: Rapid diversification of a species-rich genus of neotropical rain forest trees, Science, 293, 2242-2245, 2001.

Ruhl, M., Bonis, N. R., Reichard, G. J., Sinninghe Damsté, J. S., and Kürschner, W. M.: Atmospheric carbon injection linked to end-Triassic mass extinction, Science, 333, 430-434, 2011.

Rull, V.: Neotropical biodiversity: timing and potential drivers, Trends in Ecology and Evolution, 26, 508-513, 2011.

Saylor, J. E. and Horton, B. K.: Nonuniform surface uplift of the Andean plateau revealed by deuterium isotopes in Miocene volcanic glass from southern Peru, Earth Planet. Sc. Lett., 387, 120 131, 2014.

Schoene, B., Guex, J., Bartolini, A., Schaltegger, U., and Blackburn, T. J.: Correlating the end-Triassic mass extinction and flood basalt volcanism at the $100 \mathrm{ka}$ level, Geology, 38, 387-390, 2010.

Sepulchre, P., Ramstein, G., Fluteau, F., Schuster, M., Tiercelin, J.J., and Brunet, M.: Tectonic uplift and eastern Africa aridification, Science, 313, 1419-1423, 2006.

Silva-Caminha, S. A. F., Jaramillo, C., and Absy, M. L.: Neogene palynology of the Solimoes Basin, Palaophytologie, 284, 13-79, 2010.

Stebbins, G. L.: Flowering Plants: Evolution above the Species Level, Belknap, 480 pp., 1974.

ter Steege, H. and RAINFOR: Contribution of current and historical processes to patterns of tree diversity and composition of Amazonia, in: Amazonia: landscape and species evolution, edited by: Hoorn, C. and Wesselingh, F. P., Wiley-Blackwell, Chichester, 349-359, 2010.

ter Steege, H., Pitman, N. C. A., Sabatier, D. et al.: Hyperdominance in the Amazonian tree flora, Science, 342, 6156, doi:10.1126/science.1243092, 2013.

Vega, A. M., Nogueira, A. C. R., Mapes, R. W., and Coleman, D. S.: A late-Miocene delta-lacustrine system in the eastern Solimoes basin: prelude to the modern Amazon, Geological Society of America Abstracts, 38, p. 144, 2006.

Wahnfried, I. and Soares, E. A. A.: Água Subterrânea na Amazônia: Importância, Estado Atual do Conhecimento e Estratégias de Pesquisa, Revista Ciência e Ambiente 44, 30-40, 2012.

Wallace, A. R.: Tropical Nature and Other Essays, Macmillan, New York, 356 pp., 1878.

Wesselingh, F. P.: Miocene long-lived lake Pebas as a stage of mollusk radiations, with implications for landscape evolution in western Amazonia, Scripta Geologica, 133, 1-17, 2006.

Westaway, R.: Late Cenozoic fluvial sequences in western Amazonia: fluvial or tidal? J. S. Am. Earth Sci., 21, 120-134, 2006.

Willis, K. I., Bennett, K. D., Bhagwat, S. A., and Birks, H. J. B.: $4{ }^{\circ} \mathrm{C}$ and beyond: what does this mean for biodiversity in the past?, Syst. Biodivers., 8, 3-9, 2010.

Zachos, J., Pagani, M., Sloan, L., and Billups, K.: Trends, rhythms, and aberrations in global climate 65 ma to present, Science, 292, 686-693, 2001.

Zalán, P. V. and Matsuda, N. S.: Bacia do Marajó, Boletim de Geociências da Petrobras, 15, 311-319, 2007. 